Synthesis, part of a Special Feature on Riverine Landscapes

\title{
Restoring Riparian Ecosystems: The Challenge of Accommodating Variability and Designing Restoration Trajectories
}

\author{
$\underline{\text { Francine M. R Hughes }}^{1}, \underline{\text { Adrian Colston }}^{2}$, and $\underline{\text { J. Owen Mountford }}^{3}$
}

\begin{abstract}
Flood disturbance processes play a key role in the functioning of riparian ecosystems and in the maintenance of biodiversity along river corridors. As a result, riparian ecosystems can be described as mobile habitat mosaics characterized by variability and unpredictability. Any river restoration initiative should aim to mimic these attributes. This paper suggests that there needs to be an increased institutional capacity to accept some levels of both variability and unpredictability in the ecological outcomes of river restoration projects. Restoration projects have frequently used some form of historical or contemporary reference system to define objectives and to help in the evaluation process. Using these reference systems can give a false sense of the predictability of ecological outcomes. We suggest that reference systems need to be used with caution for six reasons: (1) there are often no appropriate reference systems to use, (2) many catchment parameters have changed since the times of chosen historic reference systems, (3) climate change has been continuous throughout the Holocene, (4) projected climate change is of uncertain magnitude, (5) alien species cannot be avoided, and (6) landscape context changes through time. As well as defining short-term objectives, we suggest that river restoration projects should also formulate longerterm (decadel) restoration trajectories that are less predictable but more representative of real system attributes. Restoration trajectories could be defined using a range of ecological outcomes to accommodate interannual variability. The challenges of defining what levels of variability are important for restoring European floodplain forests are used to demonstrate the difficulties of broadening approaches and creating trajectories. In particular, the changing significance of variability at different spatial and temporal scales is discussed. An account is given of a restoration project at Wicken Fen in the United Kingdom in which nondeterministic approaches to goal setting have been initiated.
\end{abstract}

Key Words: river restoration; predictability; variability; restoration trajectories; reference systems; Wicken Fen; floodplain forests; restoration objectives; restoration evaluation

\section{INTRODUCTION}

Variability, both physical and biological, is the hallmark of a fully functional river system. The sources of this variability can be found in short- and long-term patterns of climate change (Edmonds et al. 2003), in alterations to runoff and sediment transfer patterns (Church 2002, Richards et al. 2002, Montgomery and Boulton 2003), and in changing hydrological and geomorphological responses to these patterns. The dependence of biota on these physical processes is reflected in the variable composition through time of plant and animal communities found both in-stream and in riparian zones (Nilsson et al. 1991b, Wissmar et al. 2003). The consequences of this variability and its connections with the attributes of dynamism and diversity in river ecosystems have been the subject of numerous reviews (Junk et al. 1989, Poff and Ward 1989, Petts 1990, Naiman and Décamps 1997). The alterations to these attributes caused by human activities such as dam construction have also been widely explored (Rood and Mahoney 1990, Nilsson et al. 1991a, Johnson 2002, Postel and 
Richter 2003).

River managers need to be able to predict what is happening in their river systems because they are responsible, among other duties, for ensuring both adequate water supplies and flood management. Over many centuries, river management has been centered on the control of river flows, usually through construction projects such as dams and embankments. Although flow patterns reflect processes taking place across a catchment, flood management has often been organized at a local rather than at a catchment scale. For example, in the UK, channel modification has been and continues to be undertaken locally by a wide range of organizations and individuals such as the Environment Agency, internal drainage boards, and private landowners (Sear et al. 2000). A common rationale behind both dam and channelization projects has been the reduction of flood risk as well as power generation and facilitation of agricultural drainage or irrigation. These projects have frequently had the effects of (1) reducing not only the connectivity between rivers and floodplains but also the variability of flows and sediment delivery patterns in river systems and (2) making river systems more predictable.

Now that river restoration has been added to the river manager's portfolio of activities, it is being assessed in the light of the risks and uncertainties that it might create. The willingness of river managers to consider floodplain restoration projects is limited by the extent to which proposals appear to pose risks in terms of flooding or riverbank erosion. In this situation, the ability to predict the outcomes of restoration projects becomes of central importance (Adams et al. 2004). Nevertheless, the restoration of a river system should increase its variability, because this is a major attribute that has been lost. At the same time, increased variability inevitably makes it more difficult to predict outcomes.

A scoping study was recently carried out in the UK to establish the need for Broad Scale Ecosystem Impact Modelling (BSEIM) that can evaluate the environmental and ecological implications of a variety of future flood management policies and practices (DEFRA/Environment Agency 2002). The main rationale for this study was to identify and eventually build predictive tools that take into account the interactions between different physical, biological, and socioeconomic processes; these tools can then be used to support the formulation of flood management policy at a wider landscape scale. This initiative is driven by the need to comply with the European Water Framework Directive (2000/60/EC), which requires River Basin Management Plans to be produced by 2015 and reflects the perceived need to maintain control as the spatial unit at which activities are planned and operated increases.

Although studies like the BSEIM study aim to reduce uncertainties by improving the modeling and predictive capacities of river catchment managers, even sophisticated predictive tools have a limited ability to predict ecosystem change and reduce uncertainty (Peters 1991, Pace 2001, Wissmar and Bisson 2003, Schumaker et al. 2004). The rising number of adaptive management strategies reflects an appreciation of these shortcomings. A review of restored wetlands in central Europe concluded, after $40 \mathrm{yr}$ of monitoring, that unexpected as well as expected successional pathways become established during restoration, and that a certain amount of unpredictability has to be taken for granted (Klötzli and Grootjans 2001).

This paper takes the view that there has to be the institutional capacity to accept relatively low levels of predictability in river restoration outcomes to accommodate system variability. Consequently, methods of project goal setting and evaluation must also be able to take variability into account over both short and long time scales. We begin with an analysis of the use of reference systems in defining goals for river restoration projects. We suggest that the use of restoration trajectories might make it easier to incorporate variability into restoration practice, and that this would be preferable to strict adherence to reference systems. The particular challenges of defining what levels of variability are important for restoring European floodplain forests are then used to demonstrate the practical and conceptual difficulties of including variability in restoration goal setting and evaluation. Finally, a case study from the UK is described in which the characteristics of the riverine landscape precluded the use of reference systems and encouraged nondeterministic approaches to restoration. 


\section{REFERENCE SYSTEMS FOR RIVER RESTORATION PROJECTS}

\section{A context for restoration}

In Western Europe, habitat management is well integrated into the mainstream of conservation practice. In the UK, for example, there are well established methods and traditions for manipulating habitats, such as coppicing a woodland or grazing a chalk grassland to achieve particular species mixes and habitat types. The whole process is quite well controlled, and outcomes are reasonably predictable (Adams 2003). These practices are usually based on forms of land management that have been practiced for hundreds of years and, apart from a few sea cliffs or mountain crags, there are no habitats that have not experienced some form of human management (Ratcliffe 1977, Adams 2003). There is a much shorter history of habitat restoration than of habitat management for conservation, although the plethora of terms used to describe different types of restoration (discussed in Adams and Perrow 1999) reflects a continuum of practices that fall somewhere between habitat management and habitat restoration. The goals of conservation and restoration have usually been defined in terms of well documented vegetation types, most recently in the UK through the National Vegetation Classification (Rodwell 1991a,b, 1992, 1995, 2000), and are therefore predictable, although they may not always be achieved. But how natural are these vegetation types?

If natural means free from human interference, then they are all far from being natural. Their landscape value is culturally determined, and their species diversity is the result of combined human activities and natural processes over millennia. This has important implications for habitat creation, because it suggests that there is a choice between designing projects that are either historically and/or culturally determined or projects that can be free of such values, focused on the installation of physical and biological processes, and exploratory in their objectives. Of course, the choice is not so clear-cut, because these are two ends of a spectrum, some natural processes occur in all ecosystems, and any choice is applied in a context of changing climate and, in the case of rivers, changing catchment variables. Ultimately, our choice is based on the levels of variability, risk, and predictability that we are prepared to accept.

\section{Limitations of reference systems}

Defining ecological goals in a river restoration project is less easy than defining technical goals for activities like flood management, and is often centered around the provision of physical conditions suitable for one or more target species (Downs et al. 2003). River restoration projects are usually carried out within the context of a river system whose state is different in many essential parameters from any previous system state. In addition, all biophysical systems are on a constantly changing trajectory through time and are essentially nondeterministic. Frequently, ecological goals are set by reference to some predetermined historical or previous condition, or a contemporary "reference" river system is used as a template. Known relationships between biota and physical parameters can also be used as a reference for refining objectives and the methods adopted to achieve them.

Using reference systems makes the definition of goals and objectives and the evaluation of success relatively straightforward. Reference systems also give river managers a greater sense of the predictability of the outcomes, although confidence in predictability may be misplaced. The degree to which the project outcomes and the reference system resemble each other can largely be decided by the way that objectives are set (Simons and Boeters 1998). Evaluation of restoration projects is similarly carried out against the reference system, although the levels of rigor used to conduct such evaluations vary considerably (Anderson and Dugger 1998, Stream Corridor Working Group 1998). In reality, river restoration outcomes are rarely assessed and evaluated (Holmes 1991, Kondolf 1995), and there are few well recorded examples of the degree to which objectives have been met. Although reference systems have obvious and important roles to play in choosing the levels of physical and ecological variability to return to a river system, there are also some issues to consider:

1. There are often no suitable contemporary reference systems to use as templates. In some cases, reference systems are chosen that might not be biogeographically matched with the system to be restored, although they are the best available. The European floodplain forests assigned to the five main categories in the Interpretation Manual of European Union 
Habitats (European Union Habitats Committee 1999) provide an example. The two most prevalent categories are "residual alluvial forests" (Category 91EO) and "mixed hardwood riparian forests" (Category 91FO). However, when combined, these two are equivalent to 16 of the subcategories defined in the European Nature Information System classification scheme. The considerable variation in species composition of these different subcategories demonstrates that, although there can be many broad functional similarities between rivers in Europe, species assemblages in their alluvial forests vary considerably and do not always serve as suitable templates for restoration projects elsewhere. However, there is often little choice because of the rarity of these forested habitats (Middelkoop et al. 2003). At the smaller spatial scale of a particular river corridor or floodplain site, the difficulties with choosing criteria for the establishment of reference riparian plant communities are discussed by Harris (1999).

2. Many catchment parameters have changed since the times of chosen historic reference systems. Even where rivers are well documented through maps and estate records, the extent to which different parameters have changed is often not known. Parameters might include flow volume and variability (Wade et al. 1998), water quality, land use and runoff patterns, and river management practices. The little ice age produced considerable changes in flow patterns in glacially fed European rivers by increasing the flood frequency in many valleys. For example, in the River Arve below the Merde-Glace Glacier on Mont Blanc in France, flooding seems to have increased during the late 16 th century in direct proportion to the advance of the ice, sometimes reinforced by sudden outflows from glacial dams (Grove 1988). The use of a historic reference condition from this period would be difficult to replicate in terms of hydrological patterns. Probst (1989) defined a number of distinct hydroclimatic periods for the period since 1800, using hydrological records from a range of large European rivers (Fig. 1). In the lower Red Deer River in Alberta, periods of higher rainfall and river flows, coupled with changes in upper catchment runoff patterns, have been shown to have promoted unusually extensive floodplain forest regeneration during the late 19th century (Cordes et al. 1997). Such extensive regeneration could not be reproduced with the flows and suspended sediment loads measured in the Red Deer River today.

3. Throughout the Holocene there has been considerable climate change, which is well documented for most countries in Europe through the use of pollen analysis and macrofossils. Although it is difficult to produce correlations between climate change and detailed changes in fluvial systems (Patton and Baker 1980), there is nevertheless evidence during the Holocene of alternating phases of stability and high flood activity in many rivers in temperate zones (Starkel 1991a). During the Holocene, many contemporary tree species existed, but the particular mixes of species found together from that period often do not have modernday analogs. There are good examples in a series of pollen profiles from Alberta, Canada, which show that white spruce (Picea glauca), poplar (Populus spp.), paper birch (Betula papyrifera), sagebrush (Artemisia spp.), and a series of grass species co-existed in the postglacial period from about 10,400 to $8000 \mathrm{BP}$ (MacDonald 1987). There is no modern-day analog for this mix of species in the region or anywhere else on the continent. There is clear evidence that the climate varied continuously through the interglacial periods, and, for this reason, trying to restore to a previously existing natural ecosystem is not necessarily a sustainable or realistic approach. Allen et al. (2001), working in the lower Mississippi Basin, suggest that trying to restore to some previous system state is less important than trying to match species and physical conditions in floodplain forest restoration programs. Perhaps the best we can hope to do is reconstruct naturalistic rather than natural assemblages of plants and animals (Berger 1991, Brookes et al. 1996). 
Fig. 1. Fluctuations in mean annual discharge in relation to the long-term mean for a range of large European river systems. Values were determined using 5-yr moving average curves. Humid intervals can be observed during the periods 1840-1850, 1910-1940, and 1960-1970 (Redrawn from Probst 1989).

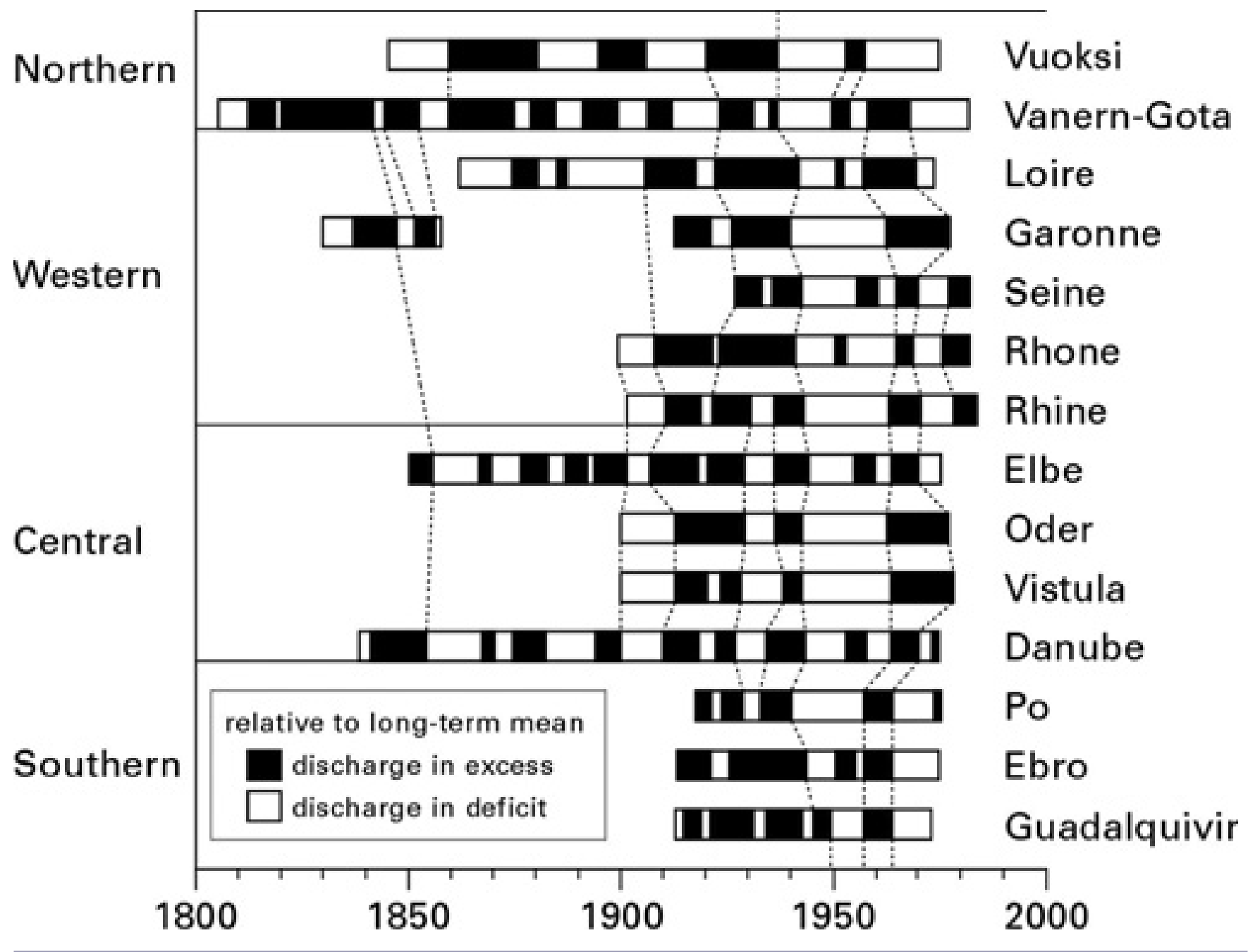

4. Projected climate change is necessarily going to affect runoff patterns and hydrological regimes. Climate variability associated with the El Niño Southern Oscillation Pattern strongly affects peak flows of snowmelt from year to year in many river basins in the northwest United States (Edmonds et al. 2003). General Circulation Models of future climate change are forecasting even greater variability with considerable variation in impacts between regions, although at present these models are not consistent or reliable.
For example, in the Pacific Northwest region of the United States, predictions of increases in winter precipitation vary from $3 \%$ to $50 \%$, depending on the model (Edmonds et al. 2003, NAST 2000). Coping with increased variability between seasons may well be one of many adjustments that have to be made by river managers and factored into any restoration project.

5. The presence of alien or non-native species 
in most river systems has increased over time. The reasons for this are varied but are associated with decreased geomorphological activity and increased human disturbance (Planty-Tabacchi et al. 1996, Council of Europe 2004). The presence of these species cannot be discounted during river restoration projects and may need to be included in predicted vegetation communities within project objectives. Changes in climate will inevitably have variable impacts on many native and alien species, e.g., through impacts on phenology and on physiological characteristics such as susceptibility to water stress. This will favor some species and not others, so that novel species assemblages can be expected along rivers. It seems likely that native and alien species will co-occur but that the effects of fluctuations in their populations will be insignificant compared to the range of variability in the abiotic components of a river system (Hengeveld 1994).

6. In a natural landscape, each location is influenced by its landscape context. In any single location, plant succession occurs, disturbances at many scales and of many types exert an influence, and habitats are modified and created. At the landscape scale, there is effectively a mobile mosaic of habitats with many variable lag effects between disturbance processes and the response by both the abiotic components and the species of that landscape. Therefore, at any point in space and time, species assemblages are probably unique in terms of precise combinations of species type, numbers, and age structure. Ideally, restoration should take place at a spatial scale that allows this mobile mosaic to continue to exist, with the understanding that it will adjust itself over the long term to climate and contingent changes. In practice, restoration often takes place at much smaller spatial scales, and thus only part of the mosaic can be restored at any point in time. If a small area within a large mobile mosaic is influenced by its location within the mosaic, restoring that small area without the larger mobile mosaic will probably produce communities that are not identical to any communities that formerly occupied that location. This can be understood by simply considering the situation with propagules that may no longer be available in the seed bank or from previous upstream sources for plant regeneration (see Andersson et al. 2000).

All of the above would suggest that variability through time is normal and that, for a given time frame, the range of that variability can be specified; by the same token, as the time frame extends, the variability will change its range and nature. They also suggest that, although short-term, well specified objectives, such as planting a predetermined area with a particular mix of floodplain forest trees, can be attained in river restoration projects, longer-term restoration trajectories should perhaps also be defined. These would be more speculative and based on acceptable or likely ranges of outcomes that admit variability into the system through time and over space. These restoration trajectories would have inherently low predictability on a year-to-year basis. However, a range of possible ecological outcomes over time could be defined by the present and projected physical system states of the river. At a practical level, this range could be defined, for example, by extreme values in available and projected hydrological time series, although, in this example, long flow records are needed to have confidence in predictions of the return periods of floods of different magnitude (Montgomery and Bolton 2003).

The process of evaluating the success of restoration projects also has to allow for variability. It is frequently the case that restoration projects are assessed and evaluated for their success only a few years after the implementation of the mitigating activities (see Mitsch and Wilson 1996). In addition, projects are often evaluated only in terms of how well they adhered to stated restoration activities, rather than outcomes. In an environment in which variability is desirable, such an assessment cannot evaluate a range of system states. Monitoring and assessment should take place over many years to get a picture of all the system states and to reduce the artificial impacts of practices such as planting vegetation instead of allowing natural regeneration to take place (Odum 1989, Mitsch 1993). Monitoring is a particularly important activity when the assessment and evaluation of projects become long-term processes. 
Table 1. Conditions required for the regeneration of many floodplain forest tree species in Europe.

\begin{tabular}{|c|c|}
\hline Requirements & Characteristics \\
\hline Flows & $\begin{array}{l}\text { - Regular flows that replenish and maintain floodplain water tables; these flows allow } \\
\text { established trees to grow } \\
\text { - Periodic high flows that cause channel movement and sediment deposition; these } \\
\text { provide potential regeneration sites and should be variable between years } \\
\cdot \text { Well timed flows through the first growing season that allow delivery of seeds to } \\
\text { the floodplain and establishment of seedlings; unseasonal high flows can cause high } \\
\text { mortality to seedlings in their first growing season }\end{array}$ \\
\hline Regeneration sites & $\begin{array}{l}\text { - Open sites because many pioneer tree species typical of floodplain forests cannot } \\
\text { tolerate competition } \\
\text { - Sites that are moist through the first growing season to facilitate regeneration } \\
\text { - Sites near the water's edge because these tend to be moister and catch organic } \\
\text { debris; however, sites right on the water's edge tend to suffer from flow disturbance } \\
\text { and waterlogging } \\
\text { - A variety of sediment types to provide regeneration niches for a variety of species }\end{array}$ \\
\hline Water table conditions & $\begin{array}{l}\text { Water tables accessible to the roots of seedlings through their first growing season } \\
\text { - Gradual recession of water tables following a flood } \\
\text { - Limited waterlogging }\end{array}$ \\
\hline Propagation materials & $\begin{array}{l}\text { Seeds that are carried by the river and deposited during floods; the phenology of } \\
\text { seed release and the timing of flood peaks are critical in any year for successful } \\
\text { establishment of seedlings } \\
\text { - Vegetative material that arrives by flood or is deposited locally } \\
\text { - Seeds that are carried in the wind; whereas seeds carried in the river always move } \\
\text { from upstream areas to downstream areas, seeds carried in the wind tend to move in } \\
\text { the direction of prevailing winds }\end{array}$ \\
\hline
\end{tabular}

\section{THE RESTORATION OF FLOODPLAIN FORESTS}

\section{Floodplain forest variability}

Floodplain forests have distinctive ecological characteristics that are strongly related to the variable flow regimes and sediment loads of their adjacent rivers. They are particularly good examples of habitats that vary visibly over short (annual) and longer (decadel) time frames. They are also, in Europe, now a rare habitat. Ninety percent of their original area has disappeared (UNEPWCMC 2000), and remaining fragments are often in critical condition. Floodplain forests are considered to be one of Europe's most threatened natural ecosystems and are listed in Annex 1 of the European Habitats Directive as being a "priority habitat type." These forests are highly mobile mosaics of small-scale habitats in various successional stages. Numerous authors have described European floodplain forests in terms of their floristic diversity in different bioclimatic zones (see Nilsson 1987, Pautou et al. 1996, Klimo and Hager 2001). The regeneration of many floodplain forest tree species is particularly dependent on various intra- and interannual flow regimes and on sediment deposition on channel margins and, by extension, on upstream catchment processes. Regeneration is also affected by the availability of propagules (Johansson et al. 1996) and by animal use of floodplains, especially herbivory (Andersen and Cooper 2000). In an unmodified river system, favorable conditions for the regeneration of these species only occurs in some years, giving a strong age structure to the forests. Their regeneration needs are described in detail in Hughes (2003) and listed in Table 1.

In some of the literature on riverine landscapes, the mobility of the habitat mosaic in floodplain forests is described in terms of turnover rates for floodplain or riparian habitats (see Kalliola and Puhakka 1988, Kangas 1989, Hughes 1997, Ward et al. 2002). Turnover rate refers to the time over which all parts 
of the floodplain have been eroded and redeposited and can be measured approximately by the age of the oldest vegetation communities on the floodplain. Channel margins turn over more frequently than areas on the outer edge of the floodplain, but turnover values usually refer to the entire floodplain system. In low-energy rivers, mobility is low and turnover rates are slow. In highenergy rivers, mobility, particularly of channel margins, is high and turnover rates are rapid. For example, the lower Amazon River is judged to have an approximate turnover period of $2000 \mathrm{yr}$ (Junk 1989), whereas the Animas River in Colorado is estimated to turn over every 100-150 yr (Baker 1990). An advantage of using turnover rates to characterize different floodplain forest systems is that they absorb the lag effects between present population levels of adult trees and the (usually different from present) flow conditions that prevailed at the time of their regeneration.

If the floodplain forest mosaic is viewed at a small spatial scale $\left(10^{2} \mathrm{~m}\right)$, habitat patches in the forest will change from year to year in response to channel movement and as individual species arrive, die, or migrate. A time-lapse view at this small spatial scale would show great variability through time in the vegetation species assemblages found there (Fig. 2). At the broader spatial scale of the reach or the whole floodplain, this variability becomes less pronounced because the balance of different habitat patches is more constant (Figs. 3A and 3B). At this scale, the overall biodiversity of the reach does not change that much over time frames of 10-100 yr (see Ward et al. 2002), except in response to river management practices or sudden changes in runoff or sedimentation patterns upstream. However, over longer periods of time (1000 yr), this balance at the reach scale might shift in response to isostatic lift or changes in climate, sea level, the availability of propagules, or the biophysical attributes of the catchment (Fig. 3C). In this scenario, shifting geomorphological processes, e.g., from aggradation to down-cutting of the river valley, and altered channel patterns cause major changes in the ecological vectors and patterns in the floodplain. In this case, the nature of the variability has changed, and the ecological outcomes are less predictable.

There are numerous good examples in the literature on European rivers that demonstrate variability and change at these different spatial and temporal scales. The impact of river management on river dynamics and the mobile mosaic of floodplain forest has been described by Pautou et al. (1997) for the Drac River (Fig. 4) and by Girel et al. (2003) for the confluence of the Arc and Isère Rivers, all in the Rhône River system in France. The evolution of river systems over postglacial time periods and the response of floodplain plant communities are well described for northern Sweden by Nilsson et al. (1991a). Studies in paleohydrology give us evidence of major changes in channel dynamics over the last 15,000 yr for a number of European rivers, including rivers in northern Finland (Koutaniemi 1991) and in Scotland (Maizels and Aitken 1991). One of the best-recorded rivers is the Vistula River in Poland, for which Starkel $(1983,1991 b)$ has described major shifts in hydrogeomorphic activity through the Holocene (Fig. 5). For the middle reaches of a range of European fluvial systems, Starkel (1991a) collates evidence to show changes in channel planform that are likely to have occurred through the Holocene. These changes reflect shifts in flood frequencies, sediment loads, and gradients; in general, reduced values tend to produce meandering rivers and increased values, braided rivers. Floodplain forests will probably have occupied floodplain zones during some of these periods and not others, depending on the climate, levels of geomorphologic activity (including mass movements in upper catchments), and the availability of propagules.

\section{Restoration trajectories for floodplain forests}

The needs of floodplain forests, listed in Table 1, show that the critical disturbance processes that drive these ecosystems are the seasonally and annually variable water and sediment inputs to floodplain reaches during floods. Such dynamic forest systems could perhaps be deemed successfully restored if they exhibit turnover of their mobile mosaics from year to year. However, there are two difficult questions to answer:

1. What turnover rate is desirable?

2. What range of flows is needed to produce this desirable turnover rate?

These questions are difficult to answer because the 
Fig. 2. At a small spatial scale (reach scale of $10^{2} \mathrm{~m}$ ), considerable changes in vegetation communities can be observed between two time periods in a geomorphologically active floodplain.

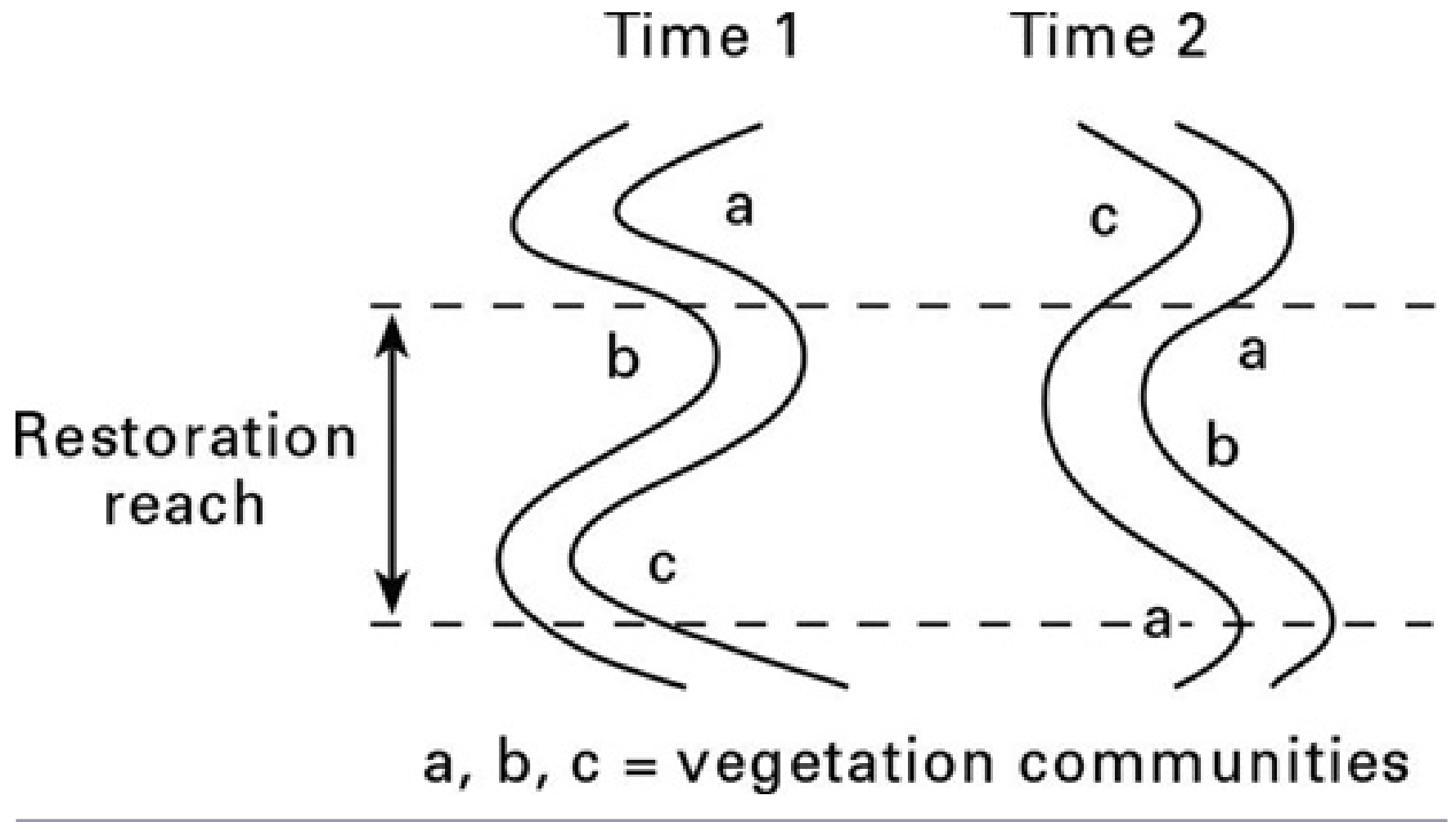

spatial and temporal scales at which these highly mobile systems are viewed affect our assessment of what levels of flow variability are important to their functioning. It is clear from the discussion above that, although there can be constancy in the balance of mosaic components over some time frames, e.g., 10-100 yr, the balance tends to follow a trajectory over longer time frames (1000 yr) or when river management practices cause rapid change over short time frames. Similarly, viewing the system at small spatial scales will tend to show greater variability through time than viewing the whole floodplain. For systems as mobile as floodplain forests, rather than defining restoration objectives in terms of precise species or habitat parameters that are assessed yearly or after only a few years, it might be preferable to outline restoration trajectories over longer time frames (decadel). This also allows for the fact that floodplain forests are dependent on processes higher up in the catchment over which a restorer will have little or no control. A restoration trajectory will in many ways broadly mimic previously existing floodplain forest systems, but, in the light of past and projected changes in river systems, might be characterized by:

1. Ranges of flow and sedimentation inputs that are not necessarily the same as those experienced in any previous time period. The timing of high and low flows might also be novel.

2. An annual balance of habitat types that varies over several decades but does not necessarily match previous balances. This can be measured by the percentage of the floodplain occupied by different species assemblages. Turnover rates can roughly be calculated by the proportion of habitats in pioneer and mature stages, with high values of pioneer habitats reflecting rapid turnover rates. 
Fig. 3. At the scale of a whole floodplain, rapid change in the distribution of floodplain vegetation communities $\mathrm{A}$ and $\mathrm{B}$ can be observed between times $t_{1}$ and $t_{2}$. However, the balance of the area occupied by these three communities remains the same (Figs. 3A and 3B). Over a longer time period, there may be changes in catchment parameters that alter the geomorphological patterns and hydrological activity of the river. By time $t_{3}$, the meandering river has become braided, and a new vegetation community (C) has arrived. The balance of floodplain vegetation communities has now changed (Fig. 3C).

A]

B]

C]

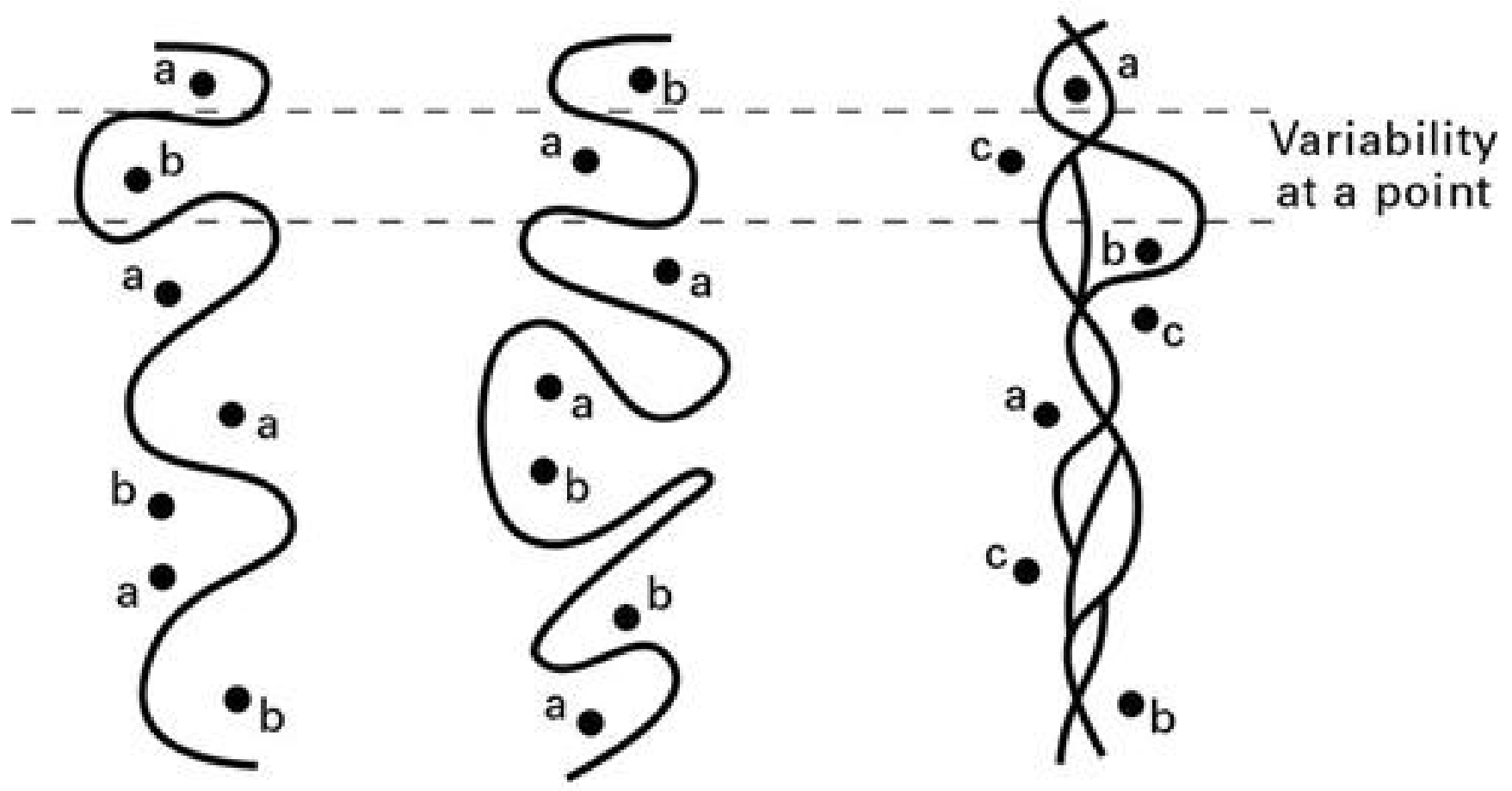

$t_{1}=4 a+3 b$

$t_{2}=4 a+3 b$

$t_{3}=2 a+2 b+3 c$

Constancy through time
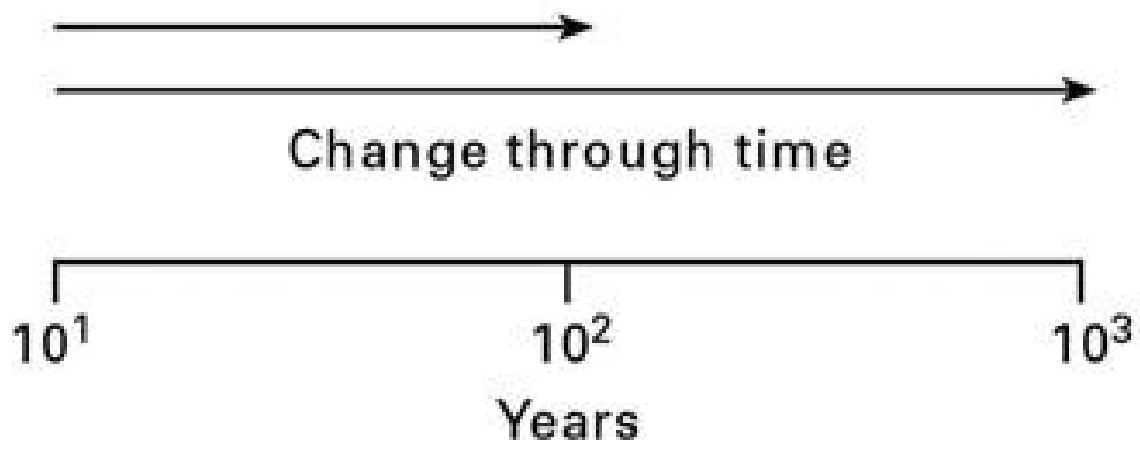
Fig. 4. Between 1948 and 1994, the River Drac in France changed from a wide, braided floodplain dominated by gravel bars to a narrower, less mobile floodplain dominated by mature woodland. Change to this floodplain was caused by gravel extraction and dam construction, which together caused channel incision and alterations to the hydrograph (Redrawn from Pautou et al. 1997).

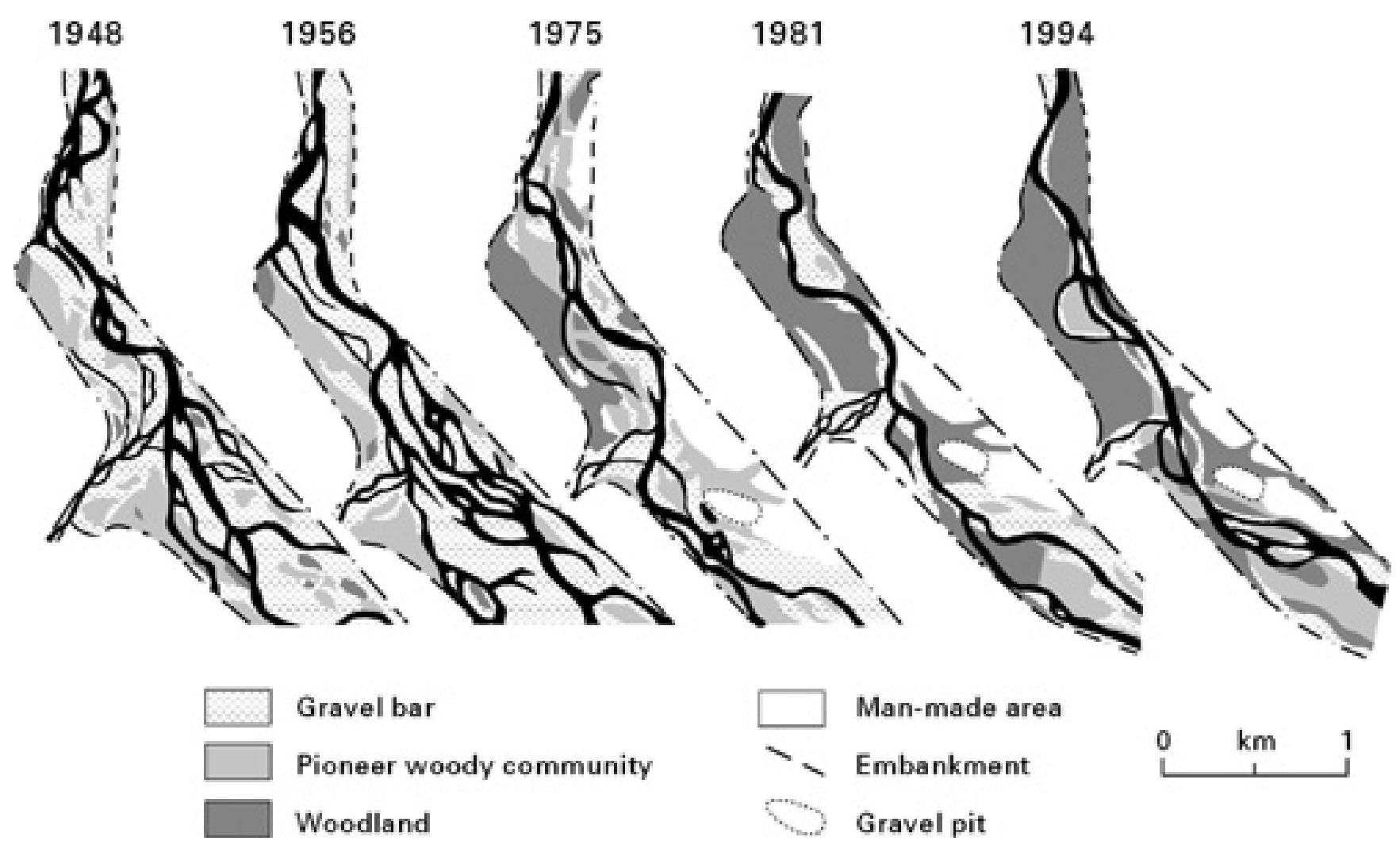

3. A range of species assemblages that might be novel because they include alien species that cannot easily be removed from the system or because dispersal routes for propagules have been changed, for example, by a dam.

The trajectory can be defined by the range of values assigned to each of these characteristics. Although the success of the restoration outcome is more difficult to assess on a yearly basis, over the decadel time frame an acceptable range of outcomes might have been achieved along the trajectory (Fig. 6). Over time, there may be a change in key physical parameters, e.g., as a result of dam construction, increased water abstraction, or global climate change. Tree regeneration patterns and the nature of the habitat mosaic will reflect changes in these key parameters, and either the restoration trajectory has to be redefined (Fig. 6) or changes to the key parameters have to be reversed or compensated for. The real difficulty with this approach is the need to reconcile a process-driven, mobile, and variable habitat with a river manager's need for a low-risk, predictable system. In addition, using a restoration trajectory is an open-ended arrangement, because it is difficult to say when the project is complete in terms of ecological outcomes. However, the approach reflects real system attributes and needs to be accommodated within the organizational, financial, and evaluation structures of river management agencies. Good collaboration with stakeholders is also needed so that ideas on openended and unpredictable approaches to habitat restoration can be more widely shared. 
Fig. 5. Variations in fluvial activity in the upper Vistula River basin, Poland, through the Holocene. Phases of increased (+) and decreased (-) fluvial activity have been identified through interpretation and dating of alluvial fills and abandoned palaeochannels. Phases of higher fluvial activity correlate with braided channel patterns, whereas stable phases correlate with meandering channel pattterns (Redrawn from Starkel 1991a).

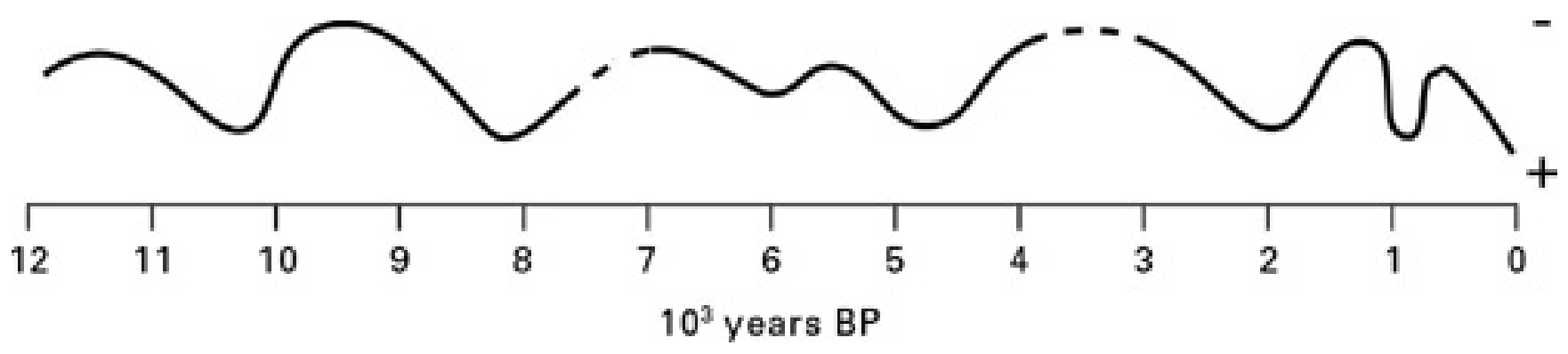

Fig. 6. A restoration trajectory over an arbitrary 24 -yr period $\left(t_{1-24}\right)$ might have been chosen to achieve an average balance of target species assemblages (-). It takes into account the great interannual variability in these species assemblages over time and demonstrates that the evaluation of projects over short time periods will be misleading. Thus, evaluation in year $t_{7}$ only would give an impression of a strong bias in favor of some species assemblages, whereas evaluations in years $t_{12-14}$ would give a very different result. When externalities such as climate parameters change, the trajectory will take a new direction (----), and restoration expectations and perhaps activities will also have to change.

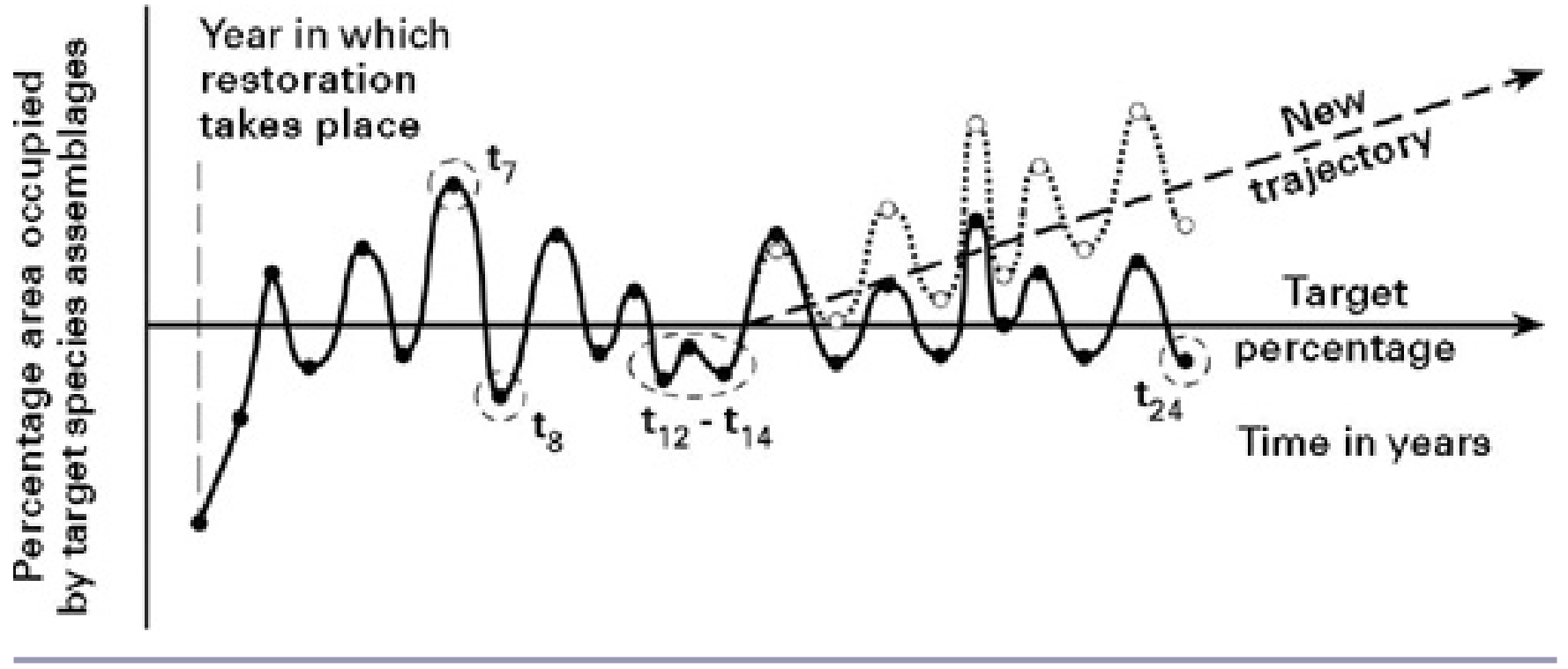


Restoration strategies for floodplain forests are not well developed in Europe because, on the whole, few river restoration schemes have been designed with the restoration of these dynamic ecosystems as a prime objective (Moss et al. 2003). There are notable exceptions, including the well documented Regelsbrunner Au Project on the River Danube and efforts to naturalize the species composition of forests through forestry practices, for example, in the Gemenc floodplain forests of the Duna-Drava National Park in Hungary. The local-scale approach to river restoration that prevails in Europe is determined by constraints on land use and hydrological manipulation (Hughes and Rood 2003) and makes it difficult to restore systems to an ecologically dynamic and physically mobile state. Catchment-scale and more process-driven approaches may become feasible using water allocation methodologies but have not been fully explored in the European context (Hughes and Rood 2003). The need for catchment-scale approaches and remobilization of floodplains has been highlighted by work on the European black poplar (Populus nigra L.), a pioneer species of floodplain forests across western and central Europe that has rapidly disappeared as rivers have become stabilized. Its genetic diversity, both within and between river basins, is closely linked to the turnover of its populations in mobile floodplain areas (Lefèvre and Kajba 2001, van Dam and Bordács 2002). In many countries there is now an interest in setting back floodplain defences and allowing rivers more space to move as a soft engineering response to the highermagnitude and more frequent floods of recent years. Opportunities for the restoration of floodplain forests seem more likely to appear as a result.

\section{RESTORATION IN A HEAVILY IMPACTED CATCHMENT: A CASE FOR NONDETERMINISTIC APPROACHES}

\section{The history of the fenland catchments of East Anglia, UK}

Some riparian landscapes are so affected by human activities that the attributes of the starting point for restoration bear no resemblance to any of the attributes of the riparian landscapes that have existed there during the postglacial evolution of the river valleys. Restoration in such catchments has to be innovative and exploratory and is largely unable to use reference systems. It may not be possible to reinstate any of the processes that characterized the former channel and floodplain systems. After evaluation of the physical and biological attributes of the catchment, a restoration trajectory can be initiated that will undoubtedly have unpredictable outcomes because there is no past experience for comparison and show considerable variability in ecological outcomes over short time scales (10 yr). There will also be opportunities to monitor and evaluate these ecological outcomes as the restoration trajectory progresses.

In the Fenland of East Anglia (UK), there is today a landscape that is characterized by a geometrical pattern of drainage ditches and straightened, slowmoving rivers. The land in between is used for intensive arable agriculture on the remnant peat soils or riverine/estuarine alluvium of what was once a vast floodplain wetland of about $3850 \mathrm{~km}^{2}$ (Moore 1997) crossed by meandering rivers. As seen in Fig. 7A, fenland rivers had well established channels in the pre-Roman period, and the coastline was inland of its present location (Astbury 1957, Rowell 1997). From Roman times until the 17th century, there was piecemeal reclamation of the fertile peat soils of the fens followed by major drainage phases during the 17th and 19th centuries. Drainage of the fens caused the peat to shrink and oxidize and land levels to drop. What was once a mobile and variable riverine landscape was turned into a static landscape with little ecological interest or biodiversity and largely canalized rivers perched 2-3 $\mathrm{m}$ above the surrounding landscape (Fig. 7B). It could be described as an inverted riverine landscape.

\section{Restoration trajectories at Wicken Fen}

Although four small nature reserves in the fenland area have preserved some fragments of the original floodplain mire, they occupy a total of only 7.13 $\mathrm{km}^{2}$. One of these, Wicken Fen National Nature Reserve, consists of 130 ha of alkaline fen on an area of undrained peat that began forming about 4000 yr BP (Gallois 1988). This nature reserve was first designated in 1899 and is owned by the National Trust. It has an exceptionally rich flora and fauna, with nearly 7000 recorded species (Friday and Colston 1999, Friday and Moorhouse 1999). It is classified as a Site of Special Scientific Interest under the UK Wildlife and Countryside Act (1981) and has been designated a Wetland of International Importance under the RAMSAR Convention (1971). It has also become part of the Natura 2000 
Fig. 7. The four main rivers of pre-Roman Fenland drained northwards into The Wash. The coastline was considerably inland of the present-day coastline (A). During the 17th century, the rivers were realigned, and an extensive drainage system was dug (B). Today the abandoned river channels remain in the form of sinuous gravel ridges, 2-3 m above the level of the land (after Astbury 1957).

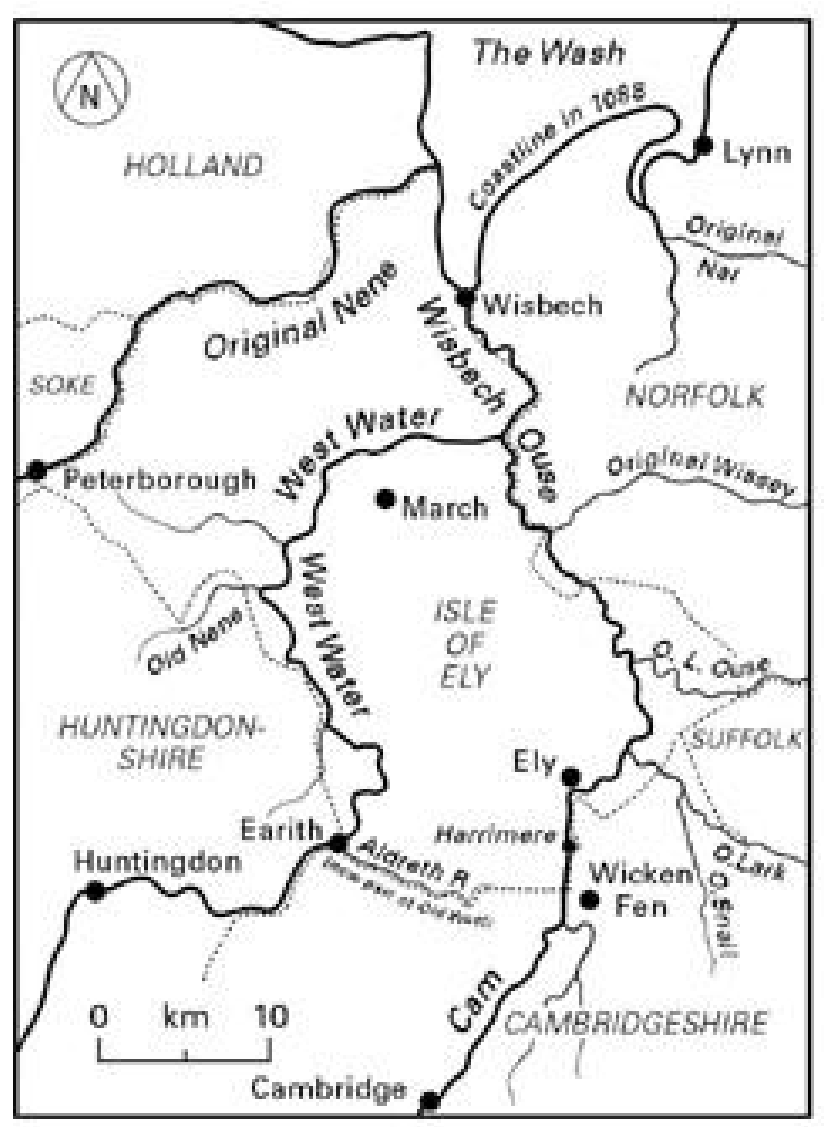

A

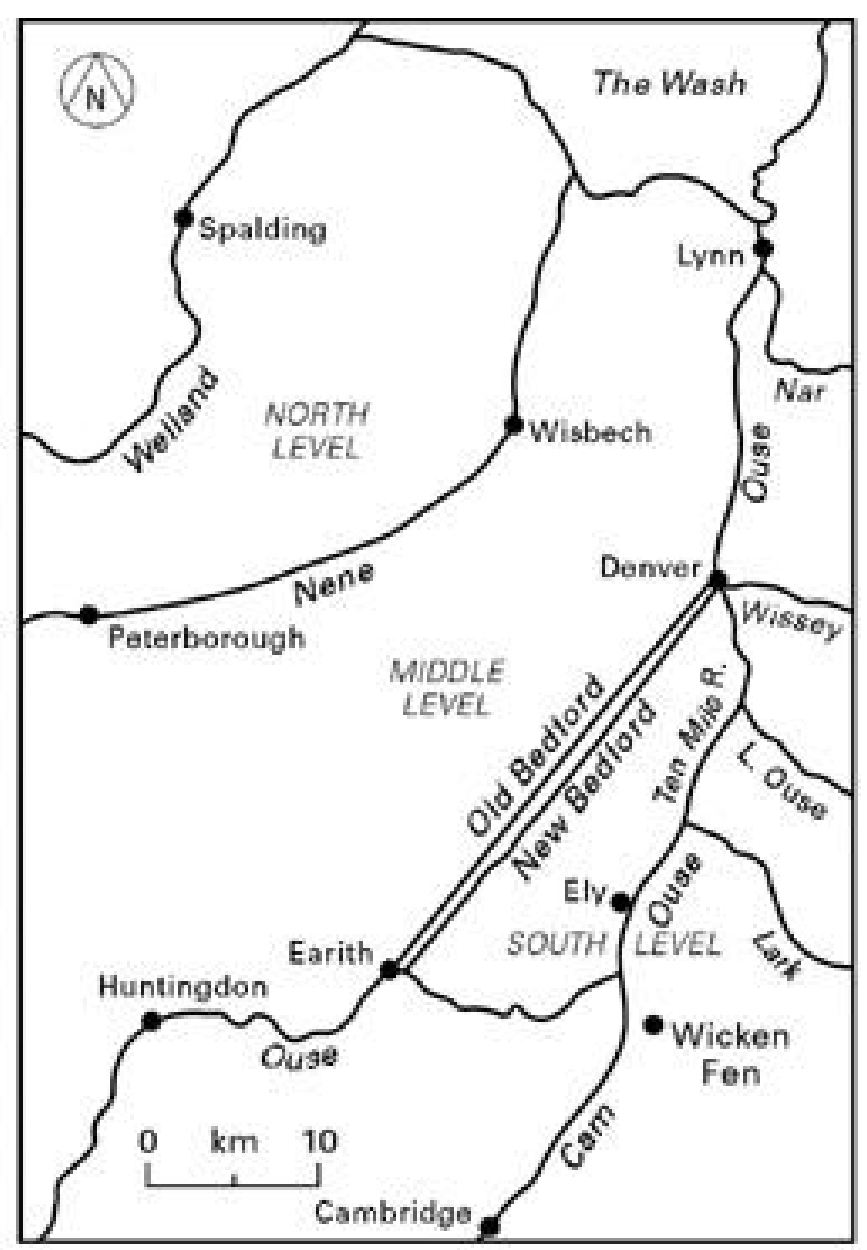

B network of Special Areas for Conservation under the EU Habitats Directive (92/43/EEC:1992), notably for its Molinia caerulea-dominated fen meadow and tall herb fen.

The program of land purchase put in place at Wicken Fen in 1992 has since grown into the "Wicken Fen 100 Year Vision" (Fig. 8). This vision has as its main aim the acquisition of 3700 ha of farmland between the nature reserve and the city of Cambridge to the south over a 100-yr period (Friday and Moorhouse 1999). The rationale behind the vision is to restore a small subcatchment of the original fenland by acquiring land and a higher degree of control over water inputs and outputs. Ultimately, the aim is to have a mobile mosaic of riparian wetland habitats within this subcatchment (Colston 2003). At the present time, 263 ha have been purchased.

The subcatchment to be restored has some difficult 
Fig. 8. A map of the 'Wicken Fen 100 Year Vision" area with the National Nature Reserve and restoration area marked.

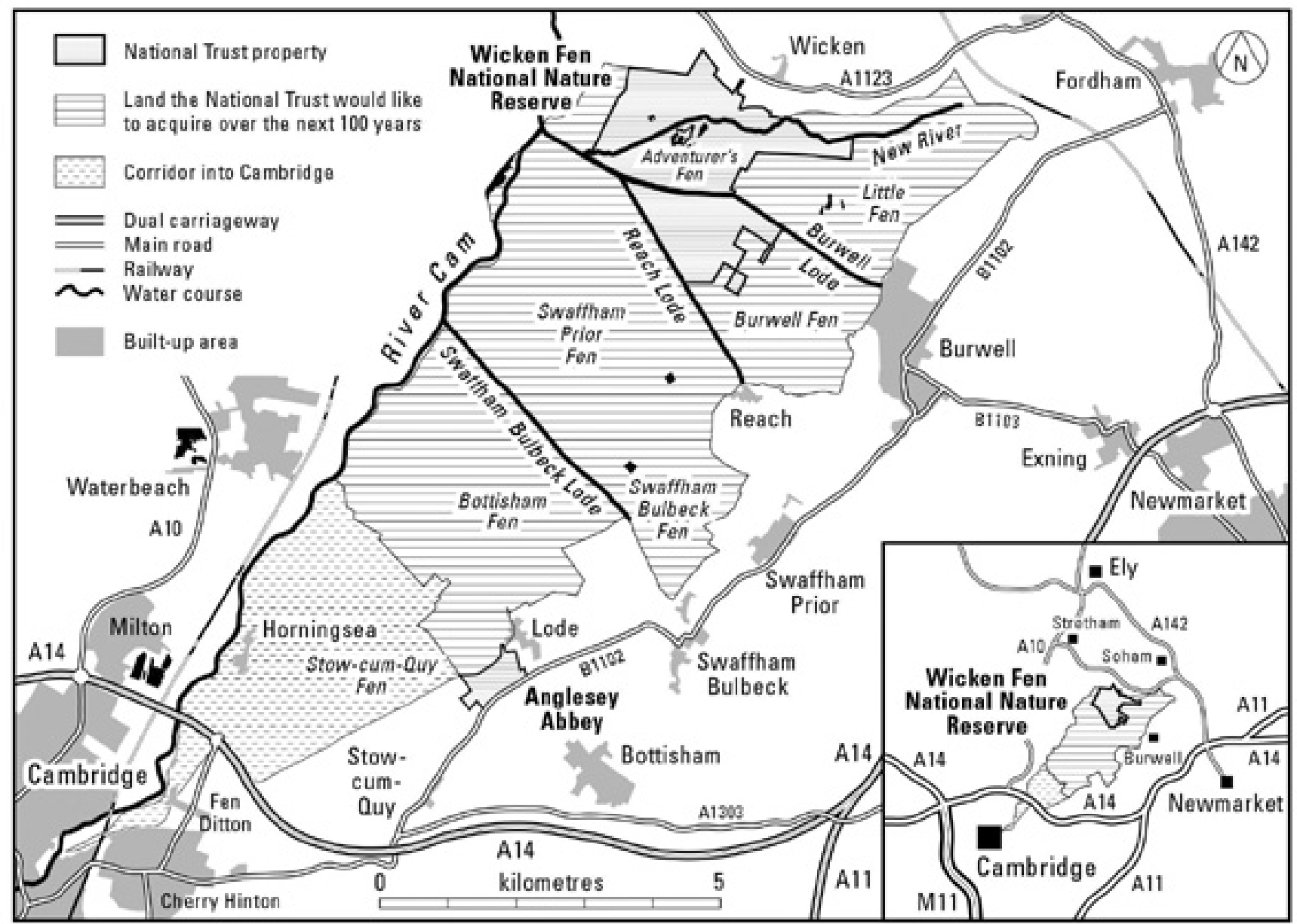

characteristics to accommodate if wetland habitats are to be recreated. Although the average annual rainfall is $530 \mathrm{~mm}$, the average annual potential evapotranspiration is $594 \mathrm{~mm}$ and exceeds rainfall from April to September (McCartney and de la Hera 2004). The annual renewable water resource is fully allocated for both groundwater and summer surface waters (Grout and Whiteman 2000). In addition, land in the subcatchment has the following characteristics that preclude the use of the original nature reserve as a reference system for restoration:

1. The original peat has largely disappeared because of drainage and arable agriculture.

2. The river system, which is managed by the Environment Agency, is perched up to $3 \mathrm{~m}$ above the land level, from which it is usually physically isolated. There is no immediate prospect of returning geomorphologically dynamic channel systems to the area.

3. There is a drainage system, managed by internal drainage boards, which lies up to 3 
$\mathrm{m}$ below the land level.

4. The seed bank in the new land is very variable, containing many arable weeds, and early reversion following the end of cultivation produces a dense mass of thistles.

5. There is an insufficient workforce to cut and mow the restored habitats.

As a result, the vision has stressed the creation of a mobile mosaic of habitats by a combination of grazing by self-reliant, free-roaming herds of animals and water level control (Friday and Moorhouse 1999). The first self-reliant herds of Konig ponies arrived on the Wicken restoration area in May 2001 and now number 26 animals. The vision has been influenced by a contemporary interest in the UK in naturalistic grazing regimes and their effect on the landscape, based largely on the work of Vera (2000), who advocates a processdriven rather than prescriptive approach to restoration with unpredictable restoration outcomes. The interest also comes from the experience in The Netherlands at the Oostvaardersplassen Nature Reserve, where 5000 ha of restored wetland are grazed by feral and wild herbivores, creating a mobile mosaic of habitats. The project in The Netherlands has not been in existence long enough to know if the balance of habitats is stable over time, nor is it known if a restoration area of this size can produce stability in habitat balance.

Essentially, the restoration area at Wicken Fen has no past or present analogs to provide an entirely appropriate reference system, although this does not preclude defining objectives that fit in with local, regional, or national objectives for habitat restoration (Mountford et al. 1999). A new ecological dynamic will be created that might consist of many novel habitats (Moorhouse 1999), although broadly they will comprise wet grasslands, reed beds, and aquatic habitats. Considerable yearto-year variability in their composition is expected, and the monitoring program is being developed to capture this variability. Compared with many restoration sites in the UK, the projected size of the site will be very large and offer enough scope for process-driven restoration with broadly defined objectives and low management intervention.
Moreover, the presence within Fenland of four other restoration sites of a comparable extent (Gerrard 2004, Mountford et al. 2004, RSPB 2003, HansonRSPB 2004) presents an opportunity to contemplate wetland restoration at a regional floodplain scale. Over time, restoration trajectories can be expected to emerge that will be defined by:

1. Sources of propagules from both the adjacent nature reserve and the past arable history.

2. The status of soils.

3. Water table levels. These will be determined by levels of physical connectivity between riparian zones and the channel and drainage systems and by abstraction from nearby channels, which in the Fens are known as "lodes."

4. The grazing habits and densities of selfreliant animal herds.

5. The impact of climate change.

At present, the Countryside Stewardship Scheme funds the restoration process. This scheme, administered through the Department for Environment, Food and Rural Affairs, provides incentives to private landowners or conservation organizations wishing to restore riparian or floodplain land. It is strictly administered, and financing can be withdrawn for noncompliance. Although most evaluation of restoration schemes has been based primarily on compliance rather than ecological outcomes, more attention has been paid to monitoring biodiversity gains in agrienvironment schemes in the last five years (Carey 2001). Nonetheless, it is difficult to evaluate the long-term ecological success of such a restoration project because novel, possibly transient, communities will have a conservation value that may be real even if not officially designated (Mountford et al. 1999). It is clear from 
experimental work at Wicken Fen that even small variations in water levels and ground treatment can have significant impacts on the particular species mixes that will appear (Xiong et al. 2003).

\section{CONCLUSION}

The motivation for ecological restoration often derives from the idea that " ... successful reconstruction of ecosystems, when it is achieved, has the reward that it is the ultimate proof of our ecological understanding ..." (Bradshaw 1983). However, this assumes that we know what kinds of ecological outcomes are desirable. In riparian ecosystems, variability and unpredictability are well marked characteristics. The spatial and temporal scales at which these mobile systems are viewed affect our understanding of what are desirable ecological outcomes. It also affects our analysis of the needs of these systems in terms of the range of variability in the physical inputs of floods and sediments significant for their functioning. For this reason, it is difficult to use reference systems in their restoration and more realistic to consider their restoration as following a trajectory rather than achieving some predetermined ecological end point.

Management of both nature reserves and restoration schemes often consists of intensive and frequent manipulation of the ecosystem to maintain or encourage the presence of some feature of designated value. This is not inappropriate in many situations, especially where restoration can only be carried out on small areas or where a specific species is being preserved. Measuring the success of such schemes may suffer both from a grossly optimistic belief in a deterministic approach to restoration and from an overcautious adherence to control and predictability. Goal setting and evaluation frequently go no further than a nostalgic embracing of some artifact such as a fen-meadow that, in real terms, is transient. The "Wicken Fen 100 Year Vision" acknowledges that nature conservation and restoration at the timescale of $10,100,1000$, or more years must allow for uncertainty. By dealing with thousands of hectares and extensive management, the vision hopes to use self-regulation at the landscape level to compensate for the losses of fragile fragments caused by localized random events.
Responses to this article can be read online at: http://www.ecologyandsociety.org/vollo/iss 1/art12/responses/

\section{Acknowledgments:}

We thank colleagues in the EU-funded project Floodplain Biodiversity and Restoration FLOBAR2 (EVK1-CT-1999-00031) for inspiring discussions over many years regarding floodplains and their restoration. Sections of this paper on European floodplain forests owe much to the work of these colleagues. We also thank the organizers and colleagues at the SISORL conference in Bredsel, Sweden, in August 2004 for stimulating discussions on river restoration. The National Trust and Local Management Committee of Wicken Fen National Nature Reserve kindly gave permission for us to use information about the restoration projects being carried out there. Our thanks to Ian Agnew from the University of Cambridge, Department of Geography, for drawing all the figures.

\section{LITERATURE CITED}

Adams, W. M. 2003. Future Nature: a vision for conservation. Earthscan, London, UK.

Adams, W. M., and M. R. Perrow. 1999. Scientific and institutional constraints on the restoration of European floodplains. Pages 89-97 in S. B. Marriott, and J. Alexander, editors. Floodplains: interdisciplinary approaches. Special Publication 163. Geological Society of London, London, UK.

Adams, W. M., M. R. Perrow, and A. Carpenter. 2004. Conservatives and champions: river managers and the river restoration discourse in the UK. Environment and Planning A 36:1929-1942.

Allen, J. A., B. D. Keeland, J. A. Stanturf, A. F. Lewell, and H. E. Kennedy, Jr. 2001. A guide to bottomland hardwood restoration. U.S. Geological Survey, Biological Resources Division Information and Technology Report USGS/BRD/ITR-2000-0011. U.S. Department of Agriculture, Forest Service, Southern Research Station, General Technical Report SRS-40.

Andersen, D. C., and D. J. Cooper. 2000. Plant- 
herbivore-hydroperiod interactions: effects of native mammals on floodplain tree recruitment. Ecological Applications 10:1384-1399.

Anderson, D. H., and B. D. Dugger. 1998. A conceptual basis for evaluating restoration success. Pages 111-120 in K. G. Wadsworth, editor. Changing resource values in challenging times; transactions of the 63rd North American Wildlife and Natural Resources Conference. Wildlife Management Institute, Washington, D.C., USA.

Andersson, E., C. Nilsson, and M. E. Johansson. 2000. Plant dispersal in boreal rivers and its relation to the diversity of riparian flora. Journal of Biogeography 27:1095-1106.

Astbury, A. K. 1957. The black fens. Golden Head Press, Cambridge, UK.

Baker, W. L. 1990. Climate and hydrologic effects on the regeneration of Populus angustifolia James along the Animas River, Colorado. Journal of Biogeography 17:59-73.

Berger, J. J. 1991. A generic framework for evaluating complex restoration and conservation projects. Environmental Professional 13:254-262.

Bloom, A. 1944. The farm in the fen. Faber and Faber, London, UK.

Bradshaw, A. D. 1983. The reconstruction of ecosystems. Journal of Applied Ecology 20:1-18.

Brookes, A., J. Baker, and C. Redmond. 1996. Floodplain restoration and riparian zone management. Pages 201-229 in A. Brookes and F. D. Shields, Jr., editors. River channel restoration: guiding principles for sustainable projects. Wiley, Chichester, UK.

Carey, P. D. 2001. Schemes are monitored and effective in the UK. Nature 414:687.

Church, M. 2002. Geomorphic thresholds in riverine landscapes. Freshwater Biology 47:541-557.

Colston, A. 2003. Beyond preservation: the challenge of ecological restoration. Pages 247-267 in W. M. Adams and M. Mulligan, editors. Decolonizing Nature: strategies for conservation in a post-colonial era. Earthscan, London, UK.
Council of Europe. 2004. European strategy on invasive alien species. Nature and Environment, Number 137. Council of Europe Publishing, Strasbourg, France.

Cordes, L. D., F. M. R. Hughes, and M. Getty. 1997. Factors affecting the regeneration and distribution of riparian woodlands along a northern prairie river: the Red Deer River, Alberta, Canada. Journal of Biogeography 24:675-695.

Department for Environment, Food, and Rural Affairs (DEFRA)/Environment Agency. 2002. Broad scale ecosystem impact modelling tools: scoping study. Final Report of project FD 2108. DEFRA Flood Management Division, London, UK.

Downs, P. W., K. S. Skinner, and G. M. Kondolf. 2003. Rivers and streams. Pages 267-296 in M. R. Perrow and A. J. Davy. Handbook of ecological restoration. Volume 2. Restoration in practice. Cambridge University Press, Cambridge, UK.

Edmonds, R. L., R. C. Francis, N. J. Mantua, and D. L. Peterson. 2003. Sources of climate variability in river ecosystems. Pages 11-37 in R. C. Wissmar and P. A. Bisson, editors. Strategies for restoring river ecosystems: sources of variability and uncertainty in natural and managed systems. American Fisheries Society, Bethesda, Maryland, USA.

European Union Habitats Committee. 1999. Interpretation manual of European Union habitats. European Union, Brussels, Belgium.

Friday, L. E., and T. A. Rowell. 1997. Patterns and processes. Pages 11-21 in L. Friday, editor. Wicken Fen: the making of a wetland nature reserve. Harley Books, Colchester, UK.

Friday, L. E., and A. Colston. 1999. Wicken Fen - the restoration of a wetland nature reserve. British Wildlife (October):37-46.

Friday, L. E., and T. P. Moorhouse. 1999. Wicken Fen: the wider vision: Report to the National Trust. University of Cambridge, Cambridge, UK.

Gallois, R. W. 1988. Geology of the country around Ely. Memoir of the British Geological Survey, Sheet 173. British Geological Survey, Nottingham, UK.

Gerrard, C. 2004. The Great Fen project. Available 
online at www.greatfen.org.uk/project.pdf.

Girel, J., F. Vautier, and J.-L. Peiry. 2003. Biodiversity and land-use history of the Alpine riparian landscapes (the example of the Isère River valley, France). Pages 167-200 in Ü. Mander and M. Antrop, editors. Multifunctional landscapes. Volume 3. Continuity and change. WIT Press, Southampton, UK.

Grout, M. W., and M. I. Whiteman. 2000. Management of groundwater resources within the Anglian Region of the Environment Agency. Pages 1.19-1.29 in Proceedings of the British Hydrological Society: 7th National Hydrology Symposium. British Hydrological Society, Newcastle, UK.

Grove, J. M. 1988. The little ice age. Routledge, London, UK.

Harris, R. R. 1999. Defining reference conditions for restoration of riparian plant communities: examples from California, USA. Environmental Management 24:55-63.

Hanson-Royal Society for the Protection of Birds (RSPB). 2004. Hanson-RSPB wetland project: creating Britain's largest reedbed for wildlife and people. RSPB, Sandy, UK.

Hengeveld, R. 1994. Biogeographical ecology. Journal of Biogeography 21:341-351.

Holmes, N. T. H. 1991. Post-project appraisal of conservation enhancement of flood defence works. Research and Development Project Report. National Rivers Authority, Bristol, UK.

Hughes F. M. R. 1997. Floodplain biogeomorphology. Progress in Physical Geography 21:501-529.

Hughes, F. M. R., editor. 2003. The flooded forest: guidance for policy makers and river managers in Europe on the restoration of floodplain forests. FLOBAR2, Department of Geography. University of Cambridge, Cambridge, UK.

Hughes, F. M. R., and Rood, S. B. 2003. The allocation of river flows for the restoration of woody riparian and floodplain forest ecosystems: a review of approaches and their application in Europe. Environmental Management 32:12-33.
Johansson, M. E., C. Nilsson, and E. Nilsson. 1996. Do rivers function as corridors for plant dispersal? Journal of Vegetation Science 7:593-598.

Johnson, W. C. 2002. Riparian vegetation diversity along regulated rivers: contribution of novel and relict habitats. Freshwater Biology 47:749-759.

Junk, W. J. 1989. Flood tolerance and tree distribution in central Amazonian floodplains. Pages 47-64 in L. B. Holm-Nielsen, L. B. Nielsen, and H. Balslev, editors. Tropical forests. Academic Press, London, UK.

Junk, W. J., P. B. Bayley, and R. E. Sparks. 1989. The flood-pulse concept in river-floodplain systems. Canadian Special Publication of Fisheries and Aquatic Sciences 106:110-127.

Kalliola, R., and M. Puhakka. 1988. River dynamics and vegetation mosaicism: a case study of the River Kamajohka, northernmost Finland. Journal of Biogeography 15:703-719.

Kangas, P. C. 1989. Long-term development of forested wetlands. Pages 25-51 in A. Lugo, M. M. Brinson, and S. Brown, editors. Forested wetlands. Elsevier, New York, New York, USA.

Klimo, E., and H. Hager, editors. 2001. The floodplain forests in Europe: current situation and perspectives. European Forest Institute Research Report Number 10. Brill, Leiden, The Netherlands.

Klötzli, F., and A. P. Grootjans. 2001. Restoration of natural and semi-natural wetland systems in central Europe: progress and predictability of developments. Restoration Ecology 9:209-219.

Kondolf, G. M. 1995. Five elements for effective evaluation of stream restoration. Restoration Ecology 3:133-136.

Koutaniemi, L. 1991. Glacio-isostatically adjusted palaeohydrology, the rivers Ivalojoki and Oulankajoki, Northern Finland. Pages 65-78 in L. Starkel, K. J. Gregory, and J. B. Thornes, editors. Temperate palaeohydrology: fluvial processes in the temperate zone during the last 15000 years. Wiley, Chichester, UK.

Lefèvre, F., and D. Kajba. 2001. Indicators for monitoring genetic diversity. Pages $36-43$ in $\mathrm{F}$. Lefèvre, N. Barsoum, B. Heinze, D. Kajba, P. 
Rotach, S. M. G. de Vries, and J. Turok, editors. In situ conservation of Populus nigra. EUFORGEN Technical Bulletin. International Plant Genetic Resources Institute, Rome, Italy.

MacDonald, G. M. 1987. Postglacial development of the subalpine-boreal transition forest of western Canada. Journal of Ecology 75:303-320.

Maizels, J., and J. Aitken. 1991. Palaeohydrological change during deglaciation in upland Britain: a case study from northeast Scotland. Pages 105-145 in L. Starkel, K. J. Gregory, and J. B. Thornes, editors. Temperate palaeohydrology: fluvial processes in the temperate zone during the last 15000 years. Wiley, Chichester, UK.

McCartney, M. P., and A. de la Hera. 2004. Hydrological assessment for wetland conservation at Wicken Fen. Wetlands Ecology and Management 12:189-204.

Middelkoop, H., J. H. Berg, M. M. van den Schoor, A. M. Alabyan, D. B. Babich, M. A. Shoubin, and J. de Krammer. 2003. Biomorphodynamics of the Allier and lower Volga rivers a reference study for river rehabilitation in the Netherlands. Page 54 in A. D. Buijse, R. S. E. W. Leuven, and M. Greijdanus-Klaas, editors. Lowland river rehabilitation 2003-an international conference addressing the opportunities and constraints, costs and benefits to rehabilitate natural dynamics, landscapes and biodiversity in large regulated lowland rivers. Netherlands Centre for River Studies, Delft, The Netherlands.

Mitsch, W. J. 1993. Ecological engineering: a cooperative role with the planetary life-support systems. Environmental Science and Technology 27:438-445.

Mitsch, W. J., and R. F. Wilson. 1996. Improving the success of wetland restoration with know-how, time, and self-design. Ecological Applications 6:77-83.

Montgomery, D. R., and S. M. Boulton. 2003. Pages 39-80 in R. C. Wissmar and P. A. Bisson, editors. Strategies for restoring river ecosystems: sources of variability and uncertainty in natural and managed systems. American Fisheries Society, Bethesda, Maryland, USA.

Moore, N. W. 1997. The Fenland Reserves. Pages
3-8 in L. Friday, editor. Wicken Fen: the making of a wetlandnature reserve. Harley Books, Colchester, UK.

Moorhouse, T. P. 1999. The restoration of fen habitats on former arable land: a literature review. Report to the National Trust. University of Cambridge, Cambridge, UK.

Moss, T., A. Klaphake, J. Monstadt, and M. Siener. 2003. What prospects for restoration? Pages 71-84 in F. M. R. Hughes, editor. 2003. The flooded forest: guidance for policy makers and river managers in Europe on the restoration offloodplain forests. FLOBAR2, Department of Geography. University of Cambridge, Cambridge, UK.

Mountford, J. O., J. M. Cooper, D. B. Roy, and E. A. Warman. 1999. Targeting areas for the restoration and re-creation of coastal and floodplain grazing marsh. English Nature Research Report Number 332. English Nature, Peterborough, UK.

Mountford, J. O., S. S. Folwell, S. J. Manchester, J. R. Meigh, R. A. Wadsworth, and M. P. McCartney. 2004. Feasibility study for wetland restoration at Baston and Thurlby Fens. Final Report to the Baston and Thurlby Fens Project Steering Group. Centre for Ecology and Hydrology, Monks Wood, UK.

Naiman, R. J., and H. Décamps. 1997. The ecology of interfaces: riparian zones. Annual Review of Ecology and Systematics 28:621-658.

National Assessment Synthesis Team (NAST). 2000. Climate change impacts on the United States: the potential consequences of climate variability and change. U.S. Global Change Research Program, Washington, D.C., USA.

Nilsson, C. 1987. Distribution of stream-edge vegetation along a gradient of current velocity. Journal of Ecology 75:513-522.

Nilsson, C., A. Ekblad, M. Gardfjell, and B. Carlberg. 1991a. Long-term effects of river regulation on river margin vegetation. Journal of Applied Ecology 28:963-987

Nilsson, C., G. Grelsson, M. Dynesius, M. Johansson, and U. Sperens. 1991b. Small rivers behave like large rivers: effects of post-glacial 
history on plant species richness along riverbanks. Journal of Biogeography 18:533-541.

Odum, H. T. 1989. Ecological engineering and selforganisation. Pages 79-101 in W. M. Mitsch and S. E. Jøgensen, editors. Ecological engineering: an introduction to ecotechnology. Wiley Interscience, New York, New York, USA.

Pace, M. L. 2001. Predictions and the aquatic sciences. Canadian Journal of Fisheries and Aquatic Sciences 58:63-72.

Patton, P. C., and V. R. Baker. 1980. Geomorphic responses of central Texas stream channels to catastrophic rainfall and runoff. Pages 189-217 in D. O. Doehring, editor. Geomorphology in arid regions. Allen and Unwin, London, UK.

Pautou, G., J. Girel, J.-L. Peiry, F. M. R. Hughes, K. S. Richards, R. Foussadier, B. GarguetDuport, T. Harris, and N. Barsoum. 1996. Les changements de végétation dans les hydrosystèmes fluviaux: l'exemple du Haut-Rhône et de l'Isère dans le Gresivaudan. Revue d'Écologie alpine 3:41-66.

Pautou, G., J.-L. Peiry, J. Girel, E. Blanchard, F. M. R. Hughes, K. S. Richards, T. Harris, A. ElHames, and R. Foussadier. 1997. Space-time units in floodplains: the example of the Drac River upstream of Grenoble (French Alps). Global Ecology and Biogeography Letters 6:311-319.

Peters, R. H. 1991. A critique for ecology. Cambridge University Press, Cambridge, UK.

Petts, G. E. 1990. The role of ecotones in aquatic landscape management. Pages 227-261 in R. J. Naiman and H. Décamps, editors. The ecology and management of aquatic-terrestrial ecotones. UNESCO/MAB Series 4. Parthenon, New York, New York, USA.

Planty-Tabacchi, A.-M., E. Tabacchi, R. J. Naiman, C. DeFerrari, and H. Décamps. 1996. Invasibility of species-rich communities in riparian zones. Conservation Biology 10:598-607.

Poff, N. L., and J. V. Ward. 1989. Implications of streamflow variability and predictability for lotic community structure: a regional analysis of streamflow patterns. Canadian Journal of Fisheries and Aquatic Sciences 46:1805-1818.
Postel, S., and B. Richter. 2003. Rivers for life: managing water for people and nature. Island Press, Washington, D.C., USA.

Probst, J.-L. 1989. Hydroclimatic fluctuations of some European rivers since 1800. Pages 41-55 in G. E. Petts, H. Möller, and A. L. Roux, editors. Historical change of large alluvial rivers: western Europe. Wiley, Chichester, UK.

Ratcliffe, D.A., editor. 1977. A nature conservation review. Cambridge University Press, Cambridge, UK.

Richards, K. S., J. Brasington, and F. M. R. Hughes. 2002. Geomorphic dynamics of floodplains: ecological implications and a potential modelling strategy. Freshwater Biology 47: $559-579$.

Rodwell, J. S., editor. 1991a. British plant communities. Volume 1. Woodlands and scrub. Cambridge University Press, Cambridge, UK.

Rodwell, J. S., editor. 1991b. British plant communities. Volume 2. Mires and heath. Cambridge University Press, Cambridge, UK.

Rodwell, J. S., editor. 1992. British plant communities. Volume 3. Grasslands and montane communities. Cambridge University Press, Cambridge, UK.

Rodwell, J. S., editor. 1995. British plant communities. Volume 4. Aquatic communities, swamps and tall-herb fens. Cambridge University Press, Cambridge, UK.

Rodwell, J. S., editor. 2000. British plant communities. Volume 5. Maritime communities and vegetation of open habitats. Cambridge University Press, Cambridge, UK.

Rood, S. B., and J. M. Mahoney. 1990. The collapse of river valley forests downstream from dams in the western prairies: probable causes and prospects for mitigation. Environmental Management 14:451-464.

Rowell, T. A. 1997. The history of Wicken Fen. Pages 187-212 in L. Friday, editor. Wicken Fen: the making of a wetland nature reserve. Harley Books, Colchester, UK. 
Royal Society for the Protection of Birds (RSPB). 2003. The Fens: the RSPB's vision for wetlands in the Fens. RSBP, Sandy, UK. Available online at www.rspb.org.

Schumaker, N. H., T. Ernst, D. White, J. Baker, and P. Hagerty. 2004. Projecting wildlife responses to alternative future landscapes in Oregon's Willamette Basin. Ecological Applications 14:381-400.

Sear, D., D. Wilcock, M. Robinson, and K. Fisher. 2000. River channel modification in the UK. Pages 55-81 in M. Acreman, editor. The hydrology of the United Kingdom: a study of change. Routledge, London, UK.

Simons, J., and R. Boeters. 1998. A systematic approach to ecologically sound river bank management. Pages 57-85 in L. C. de Waal, A. R. G. Large, and P. M. Wade, editors. Rehabilitation of rivers: principles and implementation. Wiley, Chichester, UK.

Starkel, L. 1983. The reflection of hydrologic changes in the fluvial environment of the temperate zone during the last 15,000 years. Pages 213-235 in K. J. Gregory, editor. Background to palaeohydrology. Wiley, Chichester, UK.

Starkel, L. 1991a. Long-distance correlation of fluvial events in the temperate zone. Pages 473-495 in L. Starkel, K. J. Gregory, and J. B. Thornes, editors. Temperate palaeohydrology: fluvial processes in the temperate zone during the last 15000 years. Wiley, Chichester, UK.

Starkel, L. 1991b. The Vistula River valley: a case study for central Europe. Pages 171-188 in L. Starkel, K. J. Gregory, and J. B. Thornes, editors. Temperate palaeohydrology: fluvial processes in the temperate zone during the last 15000 years. Wiley, Chichester, UK.

Stream Corridor Working Group. 1998. Stream corridor restoration: principles, processes and practices. Federal Interagency Stream Restoration Working Group, U.S. Department of Agriculture, Washington, D.C., USA. Available online at www.nrcs.usda.gov.

UNEP-World Conservation Monitoring Centre (WCMC). 2000. European forests and protected areas: gap analysis. Technical Report. UNEPWCMC, Cambridge, UK.
Vera, F. W. M. 2000. Grazing ecology and forest history. CABI Publishing, Wallingford, UK.

Van Dam, B. C., and S. Bordács, editors. 2002. Genetic diversity in river populations of European black poplar: implications for riparian eco-system management; proceedings of an International Symposium on Genetic Diversity in River Populations of European Black Poplar. (Szekszard, Hungary, 2001). Verlag C. Nyomda, Budapest, Hungary.

Wade, P. M., A. R. G. Large, and L. C. de Waal. 1998. Rehabilitation of degraded river habitat: an introduction. Pages 1-10 in L. C. de Waal, A. R. G. Large, and P. M. Wade, editors. Rehabilitation of rivers: principles and implementation. Wiley, Chichester, UK.

Ward, J. V., K. Tockner, D. B. Arscott, and C. Claret. 2002. Riverine landscape diversity. Freshwater Biology 47:517-539.

Wissmar, R. C. and P. A. Bisson. 2003. Strategies for restoring river ecosystems: sources of variability and uncertainty. Pages 3-7 in R. C. Wissmar and P. A. Bisson, editors. Strategies for restoring river ecosystems: sources of variability and uncertainty in natural and managed systems. American Fisheries Society, Bethesda, Maryland, USA.

Wissmar, R. C., J. H. Braatne, R. L. Beschta, and S. B. Rood. 2003. Variability of riparian ecosystems: implications for restoration. Pages107-127 in R. C. Wissmar and P. A. Bisson, editors. Strategies for restoring river ecosystems: sources of variability and uncertainty in natural and managed systems. American Fisheries Society, Bethesda, Maryland, USA.

Xiong, S., M. Johansson, F. M. R. Hughes, A. Hayes, K. S. Richards, and C. Nilsson. 2003. Interactive effects of soil moisture, vegetation canopy, plant litter and seeds on diversity in a British wetland plant community. Journal of Ecology 91:976-986. 